\title{
Üniversite Öğrencilerinin Yaşadıkları Sosyo-Ekonomik Sorunlar Üzerine Bir İnceleme
}

\author{
Hüseyin Doğan ${ }^{1 *}$, Gökçe Akçalı² \\ 'Muş Alparslan Üniversitesi, Bulanık Meslek Yüksekokulu, Sosyal Hizmet ve Danışmanlık Bölümü, Muş, Türkiye \\ ${ }^{2}$ Muş Alparslan Üniversitesi, Muş, Türkiye \\ ORCID: H. Doğan (0000-0002-0375-8437), G.Akçalı (0000-0003-1962-5089)
}

\begin{abstract}
Özet
Bu çalışmanın amacı üniversite öğrencilerinin yaşadıkları sosyo-ekonomik sorunların boyutu ve sosyal yardımlara erişim biçiminin tespit edilmesidir. Çalışmada nicel araştırma yöntemlerinden tarama modeli kullanılmıştır. Çalışmanın örneklemini İstanbul, Ankara, İzmir, Erzurum, Van, Muş, Batman, Gümüşhane, Bitlis, Konya illerine bağlı 10 üniversitede öğrenimine devam eden 1326 ön lisans, lisans, yüksek lisans, doktora öğrencisi oluşturmuştur. Google Form üzerinden yapılan araştırmaya 984 (\%74.2) kadın, 342 (\%25.8) erkek öğrenci katılmıştır. Ölçme aracını araştırmacı tarafından oluşturulan anket formu oluşturmaktadır. Çalışma kapsamında öğrencilerin demografik bilgileri ile karşılaştırmalı olarak ki-kare, bağımsız örneklem t testi, ANOVA, frekans gibi analizler yapılmıştır. Araştırma bulguları, kadınların erkeklere nazaran ekonomik anlamda daha çok zorluk yaşadıklarını göstermektedir. Ayrıca üniversiteye yeni gelen öğrencilerin bir üst sınıftaki öğrencilere göre daha fazla zorlandıkları ve maddi açıdan zorlanma düzeyi artan öğrencilerin üniversitede bir işte çalışmaya başladıkları belirlenmiştir. Sağlıklı bir toplumun inşasında etkin bir rol alan bu grubun üniversite döneminde aileden uzaklaşmaya bağlı olarak yaşadıkları ekonomik sorunların boyutunun tespit edilmesi önem taşımaktadır. Ayrıca üniversite öğrencilerinin bu mevcut sorunlarının toplumsal gelişim bağlamında irdelenmesinin iyileştirme sürecinde geliştirilecek politikalara katkı sağlayacağı düşünülmektedir.
\end{abstract}

Anahtar Sözcükler: Üniversite öğrencileri; ekonomik sorunlar; sosyal yardım

\section{An Analysis on Socio-Economic Problems of University Students}

\begin{abstract}
The purpose of this study is to determine the extent of the socio-economic problems experienced by university students and their access to social assistance. In the study, the scanning model, one of the quantitative research methods, was used. The sample of the study consists of 1326 associate, undergraduate, graduate and doctoral students who continue their education in 10 universities in İstanbul, Ankara, İzmir, Erzurum, Van, Muş, Batman, Gümüşhane, Bitlis and Konya. 984 (74.2\%) female and 342 (25.8\%) male students participated in the study conducted via Google Form. The survey tool consists of a questionnaire created by the researcher. Within the scope of the study, analyses such as qi-square, independent sample $t$ test, ANOVA, frequency were made in comparison with the demographic information of the students. Research findings show that women experience more economic difficulties compared to men. In addition, it has been determined that the students who are new to the university have more difficulties than those in the upper class and the students whose economic strain increased started to work while studying. It is of great significance to determine the extent of the economic problems experienced by this group, who play an active role in the construction of a healthy society, due to departure from the family during the university period. Besides, examining these existing problems of university students in the context of social development is thought to contribute to the policies to be developed during the improvement process.
\end{abstract}

Keywords: University students; economic problems; social assistance.

\section{GiRiş}

Üniversite öğrencileri, üniversite hayatına adım atmaları ile beraber gerek aile hayatından uzaklaşmaları gerek kendi benliklerinin farkına varmaları gerekse hayata karşı bakış açılarının değişmesi sonucu dıș etkilere açık hale

*Yazışma Adresi / Address for Correspondence: Yazzar, Email: shuhuseyindgn@gmail.com

Geliş Tarihi / Received Date: 26.03.2021

Kabul Tarihi / Accepted Date: 02.05.2021

Doi: 10.26701/uad.903559 gelmeye ve kendi özgür seçimlerini daha belirgin șekilde yaşamaya başlarlar. Bu süreçte de akademik, psikolojik, sosyal, kültürel, ekonomik, sağlık gibi farklı alanlarda birçok sorunla karşılaşmaktadırlar. Bu sorunlar kişisel gelişimlerine de önemli düzeyde etki etmektedir. Avcı (2010, s.29)'a göre öğrenciler öğrenim ve mesleki alandaki kaygılarının yanında toplumsal birtakım sorunlar da yaşayabilmektedir. Ona göre bu problemlerden ilki, öğrencilerin ailelerinden kaynaklı ortaya çıkan problemlerdir. Bir diğeri ise eğitim düzeyine bağlı olarak ortaya çıkan problemlerdir. Bu gibi sorunların yaşanmama- 
S1 için gerekli koșulların sağlandığı ailelerde öğrenciler kendi bireysel gelişimlerini daha iyi tamamlamaktadır. Genel olarak, sosyal çevreye uyum sağlama sürecinde ebeveynlerinden uzakta yaşamla mücadele eden öğrencilerin istek ve arzularının dikkate alınması gerektiği ve ebeveynlerin öğrencilere destek olması gerektiği vurgulanmaktadır (Avcı, 2010, s.29). Ayrıca Kacur ve Atak (2011)'a göre, ergenlik ile yetişkinlik arasındaki döneme denk gelen üniversite hayatı, kimlik kazanımını oluşturmada birey için önemli bir basamaktır. Öğrenciler, yeni karşılaştıkları üniversite ortamıyla birlikte akademik ve sosyal ortamına uyum gösterme, akademik alandaki beklentiler ve bu konudaki talepleri karşılama, bu süreçte bağımsız olmayı kazanma, çevresindeki arkadaş grubu ve karşı cins ile olan ilişkilerini sorgulama, çeşitli kariyer olanaklarını araştırma vb. birçok konuda tek başlarına baş etmek zorundadırlar (Gizir, 2005, s.197). Bu sürecin gençler üzerindeki en önemli etkisi ise karakterlerini, geleceğe bakış açılarını geliştirmeleri, kendi benliklerini bulmalarında önemli rol oynamaktadır. Gençlerin uyum sağlayabilmesi ancak karşılaşmış olduğu sorunlarla başa çıkma stratejilerini geliştirmesine bağlıdır. Bu da öğrencilerin karşılaşacağı olumsuzlukları azaltabilecek becerileri edinmesi, okula ve toplumsal çevreye uyum sağlaması ile mümkündür.

Üniversite öğrencilerinin büyük bir kısmının, ailelerinden uzakta bir yaşam sürmek zorunda olmaları, ebeveyn ve akraba gibi sosyal destek sistemlerinden uzaklaşmalarına neden olmaktadır (Yamaç, 2009, s.3). Nitekim Özgüven (1992) de üniversite çağındaki bireylerin üniversite yaşamına geçmeleriyle birlikte ailesiyle olan iliş̧kilerinin azaldığını ve bireyin davranışlarını yönlendirme noktasında üniversitedeki arkadaş çevresinin daha etkili olduğunu ifade etmektedir. Bütün bunlar da öğrenci üzerinde büyük bir etkiye neden olabilmektedir. Bunların yanı sıra öğrenciler, yoğun ders yükü, ailesel birtakım faktörler ve yeni çevrenin etkisinde yaşamış oldukları ekonomik sıkıntılar ve geleceğe yönelik endişe gibi pek çok olumsuz durumla karşılaşabilmekte ve bu sorunlarla ailelerinden uzakta tek başlarına yüzleşmektedirler. Bu süreç akabinde de toplumsallaşır ve topluma uyum sağlayan bireyler haline gelirler.

Üniversite hayatı birey için hem heyecan verici hem de zorluklar ve değişimlerle dolu bir olaylar zinciridir. Bireylerin üniversite öncesi bakış açısını; içerisinde bulunduğu sosyal yapı, çevresel etkenler, ailesi veya öğretmenleri şekillendirir. Bireyler o yapıda yaşamını sürdürür fakat üniversite hayatında birey kendi fikir, istek ve bakış açısı doğrultusunda yaşamını idame ettirme yolunu tercih eder. Üniversiteyi ailesinden uzakta okuma fikri ilkin her ne kadar öğrenciye cazip gelse de ilerleyen süreçte üniversitenin getirmiş olduğu zorluklar öğrenci tarafından kısa süre içerisinde fark edilir. Nitekim Ağır (2007)'a göre üniversitede tüm çaba ve yapılanların ödüllendirileceği, çok fazla çalışma isteği, gelecek konusunda hevesli olma insanı olumlu birtakım duygulara sürükler. Her ne kadar üniversite yaşamında öğrenci zorluklarla yüzleșse de bu duygular öğrencinin akademik anlamda başarısını da beraberinde getirmektedir. Bireyin özgür bir birey olarak yaşamını idame ettirme isteğinin yanında ailesinden uzak bir yaşam sürmeye başlamasıyla yaşamını sürdürebilmek için birtakım yükümlülüklerinin olduğu da bir gerçektir. Bunlar barınma, yeme-içme, temizlik, güvenlik gibi temel ihtiyaçlardır.

Üniversite öğrencilerinin birçoğu üniversiteyi aile ve akrabalarından uzakta okumaktadır (Gülerman, 1989, s.161). Kişisel gelișim noktasında bireyin kendini sürekli yenilediği ve sürekli desteğe ihtiyaç duyabildiği bu dönemde ailesinden uzakta kalmasının öğrencinin hayatla tek başına mücadele etmesine olanak sağlamasına ve birçok sorunu tek başına çözmek zorunda kalmasına neden olmaktadır. Bu da endişe düzeylerini artırabilmekte ve bireylerin çevrelerinde meydana gelen değişimler ya da birtakım belirsizlikler de kişilerde strese sebep olabilmektedir. Şahin (1999)'e göre öğrenciler için farklı düzeylerde etkileri olan bu durum, öğrencilerin üretkenliğini, yaratıcılığını, sosyal ilişkilerini ve uyumunu, fiziksel ve psikolojik sağlığını etkilemektedir. Ailelerin çocuk üzerinde sevgi-saygı, dayanışma, güven duygusu ve ekonomik destek gibi noktalardaki desteği, yaşamın her döneminde olduğu vurgulanmakta ve bunun da çocukların kaygı düzeylerini azalttığı belirtilmektedir (Deveci vd., 2012, s.195). Çevre faktörünün ve ailenin ekonomik durumunun öğrenci üzerinde büyük bir etkisinin olduğu var olan bir gerçektir. Yaylacı (2005)'ya göre, ulaşım ve konaklama sorunları, sosyo-kültürel değerlerin değişimleri, bireyin maddi durumu vb. gibi birtakım faktörlerin değişimi bireylerin özel yaşamlarını etkilediği gibi kariyer gelişimlerini de etkilemektedir. Birey farkında olmadan eski alışkanlıklarını yeni çevre düzenin de farklılaşması sebebi ile değişmeye, gelişmeye ve yeniden șekillendirmeye başlamaktadır. Ayrıca değişimler karşısında ne yapacağını bilmenin bireylerin uyum sürecini daha rahat bir șekilde geçirmesini sağlaması da kaçınılmazdır.

Gençler yeni adım atmış oldukları öğrenim hayatlarında temel ihtiyaçlarını karşılayacak barınma, beslenme, sağlıklı yaşama, güven içerisinde hayat sürme gibi bireysel ihtiyaçlarını karşılamak zorundadırlar. Bu süreçte öğrenciler büyük bir ekonomik külfet içerisine girebilmekte ve büyük zorluklar yaşayabilmektedir. Adem (1993, s.139-140)'e göre öğrencilerin ders kitapları, ders araç gereçleri, kırtasiye alımı, barınma, ulaşım gibi ihtiyaçları aileleri zorlayabilmektedir. Yükseköğretim ücretsiz olsa bile kişinin yaşamını idame ettirmesi için ihtiyaçlarını da okurken karşılamak zorunda kalmakta ve bu da ekonomik yoksunluk içinde yer alan aileleri umutsuzluğa sürükleyebilmektedir. Bu durumdaki ailelerden gelen öğrenciler sınırlı olan zamanlarını farklı şekilde değerlendirmekten yoksun oldukları için "fırsat maliyeti" ile karşı karşıya kalabilmektedir. 
Öğrenciler üniversitelerde ihtiyaçlarını karşılamak için çeşitli kaynaklara başvurmaktadır. Bunların başında da aile gelmektedir. Aile içerisinde dayanışmanın güçlü olduğu Türkiye'de ailelerin çocukları için özverili davrandıkları gözlemlenmektedir. Fakat öğrencilere olan parasal destek miktarı ailelerin gelirleri ile oranlı olmaktadır (Albrecht ve Ziderman, 1992). Bazı öğrenciler de üniversitedeki giderlerini karşılamak için ücretli bir işte çalışma ile birlikte eğitim hayatlarını sürdürmeye çalışmaktadır. Bireysel harcalamalarını karşılamak için başvurulacak kaynaklardan bir tanesi de kuşkusuz devlettir. Pek çok ülkede olduğu gibi ülkemizde de öğrenim kredisi, burslar gibi parasal; yurt sağlama, yemek gibi parasal olmayan yardımlar sunulmaktadır. Ayrıca kamu, özel işyerleri, dernek, vakıf gibi kuruluşlar da öğrencilere ayni-nakdi yardımlar sunabilmektedir (Kurul Tural, 1996).

Üniversite öğrencilerine yönelik sosyal yardımların bireysel maliyetlerini karşılamakta güçlük çeken öğrenciler ve onların aileleri için önemli olduğu bilinmektedir. Özellikle öğrencilerin hayatlarını kolaylaștırmak, temel ihtiyaçlarını karşılamak ve toplumsal uyumlarını sağlamak amacıyla Gençlik ve Spor Bakanlığı Kredi Yurtlar Kurumu, dernekler, vakıflar, iş adamları ve bazı kamu kurum ve kuruluşları tarafından öğrencilere yönelik burs ve kredi desteği sağlandığ bilinmektedir. Orta veya alt gelir grubuna yönelik olan burs veya kredi desteğiyle öğrenciler rahatlamakta ve ekonomik sıkıntılardan bir nebze olsa da kurtulabilmektedir. Bu da onları ve ailelerini büyük bir maddi külfetten kurtarmaktadır. Üniversite çağına gelmiş bireylerin ülkenin kalkınmasında etkin rol alabileceği düşünüldüğünde toplumun gelișimi açısından bu grubun önemi azımsanamayacak düzeydedir. Toplumun inşasında etkin bir şekilde rol alması beklenen önemli bir grubun üniversite döneminde ailesinden uzaklaşmasına bağlı olarak yaşadıkları ekonomik sorunların boyutunun tespit edilmesi noktasında önem taşımaktadır. Ayrıca sağlıklı bir toplumun gelişimi için üniversite öğrencilerinin var olan bu sorunlarının irdelenmesi, iyileştirilme sürecinde geliştirilecek politikalara katkı sağlayacağı düşünülmektedir. Bu kapsamda çalışma çıtıları göz önünde bulundurularak üniversite öğrencilerinin sosyal yardımlara ilişkin yaşadıkları problemler araştırılarak öğrencilerin aile, eğitim ve sosyo-ekonomik durumları incelenmiştir. Araştırmadan elde edilen bulgular ile öğrencilerin sosyo-ekonomik durumlarının tespit edilmesi sağlanarak bu konuda alınacak önlemlere katkı sağlaması planlanmaktadır. Bu doğrultuda üniversite öğrencilerinin ekonomik açından yaşam şartları, eğitim-barınma durumları, sosyo-ekonomik durumları ortaya konmaya çalışılmıştır. Ayrıca çalışma kapsamında şu alt sorulara da cevap aranmaya çalışılmıştır;

a) Üniversite öğrencilerinin maddi açıdan zorlanma düzeyi ve maddi ihtiyaçlarını karşılayabilme düzeyi ile aktif çalışma durumu arasında bir ilişki var mı? b) Üniversite öğrencilerinin sosyal yardımlara erişmede tercih ettiği yol/yöntemler nelerdir? Bu yol-yöntemler demografik özelliklere (cinsiyet, yaş, barınma vb.) göre değişiklik gösteriyor mu?

c) Üniversite öğrencilerinin mali olarak gelir kaynakları nelerdir? Bu kaynaklar demografik özelliklere (cinsiyet, yaş, barınma vb.) göre değişiklik gösteriyor mu?

d) Üniversite öğrencilerinin ekonomik açından zorlanma düzeyleri nasıldır? Bunlar demografik özelliklere (cinsiyet, yaş, barınma vb.) göre değişiklik gösteriyor mu?

\section{2. ÖNTEM}

\subsection{Araştırmanın Modeli}

Yapılan bu çalışmada genel tarama modeli temel alınmıştır. Karasar (2013)'a göre tarama modelleri, şu anda veya geçmişte bir zamanda bir şeyi olduğu gibi betimlemeyi amaçlayan yaklaşımlardır. Ona göre, çalışmaya konu olan olay, durum, nesne vb. olgular kendi koşulları içerisinde olduğu gibi tanımlanır. Bunun yanında var olan olgu, durum veya nesneyi değiştirme veya etkileme çabası içerisine girilmez ve bilinmek istenen şey doğru yaklaşım biçimi sergileyerek onu tespit etmektedir (Karasar, 2013).

\subsection{Evren ve Örneklem}

$\mathrm{Bu}$ çalışmanın evrenini İstanbul, Ankara, İzmir, Erzurum, Van, Muş, Batman, Gümüşhane, Bitlis, Konya illerinde öğrenim gören üniversite öğrencileri oluşturmaktadır. Bu kapsamda tesadüfi yöntemle belirlenen 10 üniversitede araştırma yürütülmüștür. Gelişigüzel örnekleme metoduyla araştırma evrenindeki okullarda okuyan 1326 öğrenci belirlenmiş ve çalışmaya katılımları gönüllülük esası gözetilerek sağlanmıştır. Araştırmaya 984 (\%74.2) kadın, 342 (\%25.8) erkek katılmıştır. Katılımcıların yaş ortalaması 20.29 olup 17-35 arasında değişkenlik göstermektedir. Ayrıca katılımcıların \%62.4'ü ( $\mathrm{f}=827)$ 17-20 yaş aralığında, \%34.2'si ( $\mathrm{f}=454)$ 21-25 yaş aralığında, \%2.7'si (f=36) 26-30 yaş aralığında ve \%0.7'si $(\mathrm{f}=9)$ 31-35 yaş aralığındadır.

\subsection{Veri Toplama Aracı}

Araştırmacılar tarafından veri toplama aracı olarak anket formu hazırlanmıştır. Ölçme aracı toplam iki bölümden oluşmaktadır. Birinci bölümde çalışmaya ilişkin sosyo-demografik bilgiler (cinsiyet, medeni durum, öğrenim düzeyi, ikamet şekli, aylık bireysel gelir, anne-baba öğrenim düzeyi gibi) yer almaktadır. İkinci bölümde ise üniversite öğrencilerinin sosyal yardımlara ilişkin durumunu ölçen sorular (sosyal yardımlara erişimi, ayni-nakdi yardım veya burs alma, alınan bursların ihtiyaçları karşılama durumu gibi) yer almaktadır.

\subsection{Veri Toplama Süreci}

Çalışma kapsamındaki üniversite öğrencilerine ulaşmak için anket formu kullanılmıştır. Araştırmaya başlamadan önce Muş Alparslan Üniversitesi Bilimsel 
Araştırma ve Yayın Etiği Kurulu'na bașvuruda bulunulmuș ve onay alınmıștır (Evrak tarih ve sayı numaras1:10/06/2019-E.8145). Etik kurul izin süreci tamamladıktan sonra sağlıklı veri toplanması amacıyla araştırmanın planlandığı okullarda okuyan öğrencilere Google form üzerinden olușturulan anket formu ön bilgilendirmeler yapılarak kendilerine sanal ortamda iletilmiş ve doldurmaları istenmiştir. Öğrenciler tarafından anket formları doldurulurken gönüllülük esası gözetilmiş ve sağlıklı veri elde edilmesi için özellikle hassasiyet gösterilmiştir.

\subsection{Verilerin Analizi}

Çalışma kapsamında elde edilen verilerin istatistiksel analizi için SPSS 22.0 programı kullanılarak veri tabanı hazırlanmış ve Google form üzerinden elde edilen veriler excel dosyası yardımıyla programa aktarılmışıı. Ardından çalışmanın amacı kapsamında ihtiyaç duyulan istatistiksel analizler yapılmıştır. Bu kapsamda katılımcıların sosyo-demografik bilgileri ile karşılaştırmalı olarak ki-kare, bağımsız örneklem $\mathrm{t}$ testi, ANOVA, frekans gibi analizler yapılmıştır.

\section{BULGULAR}

Çalışmanın bu bölümünde araştırma kapsamındaki alt problemler doğrultusunda elde edilen bulgulara yer verilmiştir.

Tablo 1. Öğrencilerin maddi açıdan zorlanma düzeyi ile aktif çalışma durumlarının karşılaştıııması

\begin{tabular}{|c|c|c|c|c|c|}
\hline & & \multicolumn{3}{|c|}{ Aktif çalışma durumu } & \multirow[b]{2}{*}{$\begin{array}{l}\text { Top- } \\
\text { lam }\end{array}$} \\
\hline & & $\begin{array}{c}\text { Tam } \\
\text { zamanlı } \\
\text { çalış̧yorum }\end{array}$ & \begin{tabular}{c|} 
Kısmi \\
zamanlı ça- \\
lışıyorum
\end{tabular} & $\begin{array}{l}\text { Çalışmı- } \\
\text { yorum }\end{array}$ & \\
\hline \multirow{8}{*}{$\begin{array}{l}\text { Zorlanma } \\
\text { Düzeyi }\end{array}$} & \multirow{2}{*}{$\begin{array}{l}\text { Evet, zorlani- } \\
\text { yorum }\end{array}$} & 24 & 53 & 759 & 836 \\
\hline & & 2.9 & 6.3 & 90.8 & 100 \\
\hline & \multirow{2}{*}{$\begin{array}{l}\text { Kismen zorlanı- } \\
\text { yorum }\end{array}$} & 24 & 10 & 360 & 394 \\
\hline & & 6.1 & 2.5 & 91.4 & 100 \\
\hline & \multirow{2}{*}{$\begin{array}{l}\text { Hayır, zorlanmI- } \\
\text { yorum }\end{array}$} & 28 & 0 & 68 & 96 \\
\hline & & 29.2 & 0 & 70.8 & 100 \\
\hline & \multirow{2}{*}{ Toplam } & 76 & 63 & 1187 & 1326 \\
\hline & & 5.7 & 4.8 & 89.5 & 100 \\
\hline
\end{tabular}

$\mathrm{p}=.01<0.05$

Tablo 1'de araştırmaya katılan üniversite öğrencilerinin üniversiteyi okurken maddi açıdan zorlanma düzeyleri ve aktif çalışma durumları karșılaştırılmıştır. Elde edilen bulgulara göre üniversiteyi okurken zorlanan öğrencilerin \%90.8'i (f=759), kısmen zorlananların \%91.4'ü (f=360) ve zorlanmayanların $\% 70.8^{\prime} \mathrm{i}(\mathrm{f}=68)$ aktif olarak herhangi bir işte çalışmamaktadır. Ayrıca yapılan analize göre, iki grup arasında anlamlı bir ilişki tespit edilmiştir $(\mathrm{p}<0,05)$. $\mathrm{Bu}$ ilişkinin de maddi açıdan zorlanma düzeyi arttıkça herhangi bir işte çalışanların sayılarındaki anlamlı artıştan kaynaklandığı belirlenmiştir.

Tablo 2'de araștırmaya katılan üniversite öğrencilerinin üniversiteyi okurken maddi açıdan ihtiyaçlarını karşılama düzeyleri ve aktif çalışma durumları karşılaştırıl- mıştır. Elde edilen bulgulara göre üniversiteyi okurken ihtiyaçlarını karşılayabilen öğrencilerin \%89.4'ü (f=59), kısmen karşılayabilenlerin \%92'si ( $\mathrm{f}=309)$ ve karşılayamayanların \%93'ü ( $\mathrm{f}=319$ ) aktif olarak herhangi bir iște çalışmamaktadır. Ayrıca yapılan analize göre, iki grup arasında anlamlı bir ilişki tespit edilmiştir $(\mathrm{p}<0,05)$. Buna göre, maddi ihtiyaçların karşılanma düzeyi azaldıkça herhangi bir işte çalışanlarının sayılarında anlamlı artış meydana geldiği saptanmıștır.

Tablo 2. Öğrencilerin maddi ihtiyaçlarını karşılama düzeyi ile aktif çalışma durumlarının karşılaştırılması

\begin{tabular}{|c|c|c|c|c|c|}
\hline & & \multicolumn{3}{|c|}{ Aktif çalışma durumu } & \multirow[b]{2}{*}{$\begin{array}{l}\text { Top- } \\
\text { lam }\end{array}$} \\
\hline & & $\begin{array}{c}\text { Tam } \\
\text { zamanlı } \\
\text { çalışıyo- } \\
\text { rum }\end{array}$ & $\begin{array}{c}\text { Kısmi } \\
\text { zamanlı } \\
\text { çalışıyo- } \\
\text { rum }\end{array}$ & $\begin{array}{l}\text { Çalışmı- } \\
\text { yorum }\end{array}$ & \\
\hline \multirow{6}{*}{$\begin{array}{l}\text { Maddi } \\
\text { İhtiyaçların } \\
\text { Karşılanma } \\
\text { Düzeyi }\end{array}$} & \multirow{2}{*}{$\begin{array}{l}\text { Evet, karşı- } \\
\text { lıyor }\end{array}$} & 7 & 0 & 59 & 66 \\
\hline & & 10.6 & 0 & 89.4 & 100 \\
\hline & \multirow{2}{*}{$\begin{array}{l}\text { Kısmen } \\
\text { karşılıyor }\end{array}$} & 11 & 16 & 309 & 336 \\
\hline & & 3.3 & 4.8 & 92 & 100 \\
\hline & \multirow{2}{*}{$\begin{array}{c}\text { Hayır, karşı- } \\
\text { lamıyor }\end{array}$} & 8 & 16 & 319 & 343 \\
\hline & & 2.3 & 4.7 & 93 & 100 \\
\hline & \multirow{2}{*}{ Toplam } & 26 & 32 & 687 & 745 \\
\hline & & 3.5 & 4.3 & 92.2 & 100 \\
\hline
\end{tabular}

$\mathrm{p}=.01<0.05$

Tablo 3'te araştırmaya katılan üniversite öğrencilerinin üniversiteyi okurken maddi açıdan zorlanma düzeyleri medeni durumları açısından karşılaştırılmıştır. Elde edilen bulgulara göre, çalıșmaya katılan bekâr öğrencilerin \%63.6'sının ( $\mathrm{f}=811$ ) üniversiteyi okurken maddi açıdan zorlandıkları, evli öğrencilerin ise \%49'unun $(\mathrm{f}=25)$ zorlandıkları saptanmıştır. Ayrıca yapılan analize göre iki gru arasında anlamlı bir ilişki tespit edilmiştir $(\mathrm{p}<0,05)$. Bu ilişkinin evli öğrencilerin bekâr öğrencilere göre maddi açıdan daha fazla zorlanmalarından kaynaklandığı saptanmıştır.

Tablo.3 Öğrencilerin medeni durumlarının maddi açıdan zorlanma düzeylerine göre dağılımı

\begin{tabular}{|c|c|c|c|c|c|}
\hline & & \multicolumn{3}{|c|}{ Zorlanma düzeyi } & \multirow[b]{2}{*}{$\begin{array}{l}\text { Top- } \\
\text { lam }\end{array}$} \\
\hline & & $\begin{array}{c}\text { Evet, zorla- } \\
\text { nıyorum }\end{array}$ & $\begin{array}{l}\text { Kısmen zorla- } \\
\text { nıyorum }\end{array}$ & $\begin{array}{l}\text { Hayır, zorlan- } \\
\text { mıyorum }\end{array}$ & \\
\hline \multirow{4}{*}{$\begin{array}{l}\text { Medeni } \\
\text { durum }\end{array}$} & \multirow{2}{*}{ Bekâr } & 811 & 381 & 83 & 1275 \\
\hline & & 63.6 & 29.9 & 6.5 & 100 \\
\hline & \multirow{2}{*}{ Evli } & 25 & 13 & 13 & 51 \\
\hline & & 49 & 25.5 & 25.5 & 100 \\
\hline & \multirow{2}{*}{ Toplam } & 836 & 394 & 96 & 1326 \\
\hline & & 63 & 29.7 & 7.2 & 100 \\
\hline
\end{tabular}

$p=.01<0.05$

Tablo 4'te araștırmaya katılan üniversite öğrencilerinin üniversiteyi okurken maddi açıdan zorlanma düzeyleri okudukları sınıflar açısından karşılaştırılmıştır. Elde edilen bulgulara göre çalışmaya katılan lisans ve ön lisans öğrencilerinden 1. Sınıfta okuyanların \%68.8'inin (f=362) zorlandı ğı, 2. Sınıf öğrencilerinin \%59.1'inin $(\mathrm{f}=251)$ zorlandığı, 3. Sınıf öğrencilerinin \%62.9'unun 
(f=122) zorlandığı ve 4. Sınıf öğrencilerinin \%60.3’ünün ( $\mathrm{f}=76$ ) üniversiteyi okurken maddi açıdan zorlandıkları saptanmıştır. Lisansüstü öğrencilerine bakıldığında ise ders dönemindeki öğrencilerin \%51.5'inin ( $\mathrm{f}=17$ ) zorlandığı ve tez dönemindeki öğrencilerin \%45.5'inin ( $\mathrm{f}=10)$ üniversiteyi okurken maddi açıdan zorlanmadıkları saptanmıştır. Ayrıca yapılan analize göre iki grup arasında anlamlı bir ilişki tespit edilmiştir $(\mathrm{p}<0.05)$. Bu ilişkiye göre sınıf düzeyi yükseldikçe üniversite okurken maddi açıdan zorlanma düzeyi düşmektedir.

Tablo 4. Öğrencilerin okuduğu sınıfların maddi olarak zorlanma düzeylerine göre dağılımı

\begin{tabular}{|c|c|c|c|c|c|}
\hline & & \multicolumn{3}{|c|}{ Zorlanma düzeyi } & \multirow[b]{2}{*}{ Toplam } \\
\hline & & $\begin{array}{c}\text { Evet, zorlanı- } \\
\text { yorum }\end{array}$ & $\begin{array}{l}\text { Kısmen zor- } \\
\text { lanıyorum }\end{array}$ & $\begin{array}{c}\text { Hayır, zorlan- } \\
\text { mıyorum }\end{array}$ & \\
\hline \multirow{12}{*}{$\begin{array}{l}\text { Okuduğu } \\
\text { sınıf }\end{array}$} & \multirow{2}{*}{ 1. sinıf } & 362 & 139 & 25 & 526 \\
\hline & & 68.8 & 26.4 & 4.8 & 100 \\
\hline & \multirow{2}{*}{ 2. sinıf } & 251 & 148 & 26 & 425 \\
\hline & & 59.1 & 34.8 & 6.1 & 100 \\
\hline & \multirow{2}{*}{ 3. sinıf } & 122 & 52 & 20 & 194 \\
\hline & & 62.9 & 26.8 & 10.3 & 100 \\
\hline & \multirow{2}{*}{ 4. $\sin I f$} & 76 & 41 & 9 & 126 \\
\hline & & 60.3 & 32.5 & 7.1 & 100 \\
\hline & \multirow{2}{*}{$\begin{array}{c}\text { Ders } \\
\text { Dönemi* }\end{array}$} & 17 & 10 & 6 & 33 \\
\hline & & 51.5 & 30.3 & 18.2 & 100 \\
\hline & \multirow{2}{*}{$\begin{array}{l}\text { Tez Döne- } \\
\text { mi* }^{*}\end{array}$} & 8 & 4 & 10 & 22 \\
\hline & & 36.4 & 18.2 & 45.5 & 100 \\
\hline & \multirow{2}{*}{ Toplam } & 836 & 394 & 96 & 1326 \\
\hline & & 63 & 29.7 & 7.2 & 100 \\
\hline
\end{tabular}

* Yüksek lisans/doktora öğrencilerini belirtmektedir. / $p=.01<0.05$

Tablo 5. Öğrencilerin cinsiyetinin maddi açıdan zorlanma düzeylerine göre dağılımı

\begin{tabular}{|c|c|c|c|c|c|}
\hline & & \multicolumn{3}{|c|}{ Zorlanma düzeyi } & \multirow[b]{2}{*}{ Toplam } \\
\hline & & $\begin{array}{l}\text { Evet, } \\
\text { zorlanıyo- } \\
\text { rum }\end{array}$ & $\begin{array}{l}\text { Kismen } \\
\text { zorlanı- } \\
\text { yorum }\end{array}$ & $\begin{array}{c}\text { Hayır, } \\
\text { zorlanmıyo- } \\
\text { rum }\end{array}$ & \\
\hline \multirow{4}{*}{ Cinsiyet } & \multirow{2}{*}{ Kadın } & 623 & 306 & 55 & 984 \\
\hline & & 63.3 & 31.1 & 5.6 & 100 \\
\hline & \multirow{2}{*}{ Erkek } & 213 & 88 & 41 & 342 \\
\hline & & 62.3 & 25.7 & 12 & 100 \\
\hline & \multirow{2}{*}{ Toplam } & 836 & 394 & 96 & 1326 \\
\hline & & 63 & 29.7 & 7.2 & 100 \\
\hline
\end{tabular}

Tablo 5'te araştırmaya katılan üniversite öğrencilerinin üniversiteyi okurken maddi açıdan zorlanma düzeyleri cinsiyet grupları açısından karşılaştırılmıștır. Elde edilen bulgulara göre çalışmaya katılan kadın öğrencilerin \%63.3'ünün ( $\mathrm{f}=623$ ) üniversiteyi okurken maddi açıdan zorlandıkları, erkek öğrencilerin ise \%62.3'ünün ( $\mathrm{f}=213$ ) zorlandıkları saptanmıștır.

Tablo 6'da araştırmaya katılan öğrencilerin üniversiteyi okurken maddi açıdan zorlanma düzeyi ile yaşları arasında yapılan ikili karşılaştırma yer almaktadır. Buna göre grupların yaş ortalamaları arasında anlamlı bir farklılık $(\mathrm{p}<0.05)$ bulunmuştur. Yapılan tukey testinde bu farkl1lığın bütün gruplardan kaynaklandığı ve yaşa bağlı olarak değiştiği gözlemlenmiştir. Üniversite okurken maddi açıdan zorlanmayanların yaş ortalamasının zorlananlara göre daha yüksek olduğu görülmektedir. Yani öğrencilerin yaşları arttıkça maddi açıdan zorlanma düzeylerinin azaldığı söylenebilir.

Tablo 6. Öğrencilerin yaşlarının maddi açıdan zorlanma düzeylerine göre dağılımı

\begin{tabular}{|c|c|c|c|c|}
\hline Zorlanma Düzeyi & Yaş & SS & F & P \\
\hline Evet, zorlanıyorum & 20.08 & 2.361 & & \\
\cline { 1 - 3 } Kısmen zorlanıyorum & 20.45 & 2.622 & \multirow{2}{*}{12.865} & \multirow{2}{*}{0.001} \\
\cline { 1 - 3 } Hayır, zorlanmıyorum & 21.39 & 3.220 & & \\
\cline { 1 - 3 } Toplam & 20.29 & 2.533 & & \\
\hline
\end{tabular}

Tablo.7 Öğrencilerin medeni durumlarının mali gelir kaynaklarına göre dağılımı

\begin{tabular}{|c|c|c|c|c|}
\hline & & Gelir kaynakları* & $f$ & $\%$ \\
\hline \multirow{13}{*}{$\begin{array}{c}\text { Me- } \\
\text { deni } \\
\text { durum }\end{array}$} & \multirow{8}{*}{ Bekâr } & Aile (Anne, baba, kardeş, amca vb.) & 1167 & 57 \\
\hline & & KYK burs veya kredi & 652 & 31.9 \\
\hline & & $\begin{array}{c}\text { Aile dışındaki kişiler (İş adamları, arkadaş } \\
\text { vb.) }\end{array}$ & 46 & 2.2 \\
\hline & & Dernek/vakıf & 51 & 2.5 \\
\hline & & Üniversite & 8 & 0.4 \\
\hline & & Kendim çalışıyorum & 111 & 5.4 \\
\hline & & Diğer & 11 & 0.5 \\
\hline & & Toplam & 2046 & \\
\hline & \multirow{5}{*}{ Evli } & Aile (Anne, baba, kardeş, amca vb.) & 22 & 37.9 \\
\hline & & KYK burs veya kredi & 4 & 6.9 \\
\hline & & Üniversite & 2 & 3.4 \\
\hline & & Kendim çalışıyorum & 30 & 51.7 \\
\hline & & Toplam & 58 & \\
\hline
\end{tabular}

* Birden fazla seçenek işaretlenmiştir.

Tablo 7'de araştırmaya katılan üniversite öğrencilerinin mali gelir kaynaklarının medeni durumlarına göre dağ1lımına yer verilmiştir. Çalışmaya katılan bekâr öğrencilerin \%57'sinin (f=1167) mali gelir kaynaklarının aileleri olduğu, evli öğrencilerin ise \%51.7'sinin (f=30) mali gelir kaynaklarının kendileri olduğu (kendileri çalışarak) görülmektedir.

Tablo.8 Öğrencilerin cinsiyetinin mali gelir kaynaklarına göre dağılımı

\begin{tabular}{|c|c|c|c|c|}
\hline & & Gelir kaynakları* & $f$ & $\%$ \\
\hline \multirow{16}{*}{$\begin{array}{l}\text { Cinsi- } \\
\text { yet }\end{array}$} & \multirow{8}{*}{ Kadın } & Aile (Anne, baba, kardeş, amca vb.) & 926 & 58.8 \\
\hline & & KYK burs veya kredi & 499 & 31.7 \\
\hline & & $\begin{array}{l}\text { Aile dışındaki kişiler (İş adamları, arkadaş } \\
\text { vb.) }\end{array}$ & 37 & 2.4 \\
\hline & & Dernek/vakıf & 37 & 2.4 \\
\hline & & Üniversite & 8 & 0.5 \\
\hline & & Kendim çalışıyorum & 61 & 3.9 \\
\hline & & Diğer & 6 & 0.4 \\
\hline & & Toplam & 984 & \\
\hline & \multirow{8}{*}{ Erkek } & Aile (Anne, baba, kardeş, amca vb.) & 263 & 49.6 \\
\hline & & KYK burs veya kredi & 157 & 29.6 \\
\hline & & $\begin{array}{c}\text { Aile dışındaki kişiler (İş adamları, arkadaş } \\
\text { vb.) }\end{array}$ & 9 & 1.7 \\
\hline & & Dernek/vakıf & 14 & 2.6 \\
\hline & & Üniversite & 2 & 0.4 \\
\hline & & Kendim çalışıyorum & 80 & 15.1 \\
\hline & & Diğer & 5 & 0.9 \\
\hline & & Toplam & 342 & \\
\hline
\end{tabular}

* Birden fazla seçenek işaretlenmiştir. 
Tablo 8'de araştırmaya katılan üniversite öğrencilerinin mali gelir kaynaklarının cinsiyetlere göre dağılımına yer verilmiştir. Çalışmaya katılan kadınların \%58.8'inin ( $\mathrm{f}=926)$ mali gelir kaynaklarının aileleri olduğu, erkeklerin ise \%49.6'sının ( $\mathrm{f}=263$ ) mali gelir kaynaklarının ailelerinin olduğu görülmektedir.

Tablo.9 Öğrencilerin yaşlarının mali gelir kaynaklarına göre dağılımı

\begin{tabular}{|c|c|c|c|c|}
\hline & & Gelir kaynakları* & $f$ & $\%$ \\
\hline \multirow{26}{*}{ Yaş } & \multirow{8}{*}{$\begin{array}{l}17-20 \\
\text { Yaş }\end{array}$} & Aile (Anne, baba, kardeş, amca vb.) & 768 & 59.4 \\
\hline & & KYK burs veya kredi & 408 & 31.5 \\
\hline & & $\begin{array}{c}\text { Aile dışındaki kişiler (İş adamları, } \\
\text { arkadaş vb.) }\end{array}$ & 25 & 1.9 \\
\hline & & Dernek/vakıf & 23 & 1.8 \\
\hline & & Üniversite & 4 & 0.3 \\
\hline & & Kendim çalışıyorum & 62 & 4.8 \\
\hline & & Diğer & 4 & 0.3 \\
\hline & & Toplam & 1294 & \\
\hline & \multirow{8}{*}{$\begin{array}{l}21-25 \\
\text { Yaş }\end{array}$} & Aile (Anne, baba, kardeş, amca vb.) & 404 & 54.1 \\
\hline & & KYK burs veya kredi & 234 & 31.3 \\
\hline & & $\begin{array}{l}\text { Aile dışındaki kişiler (İş adamları, } \\
\text { arkadaş vb.) }\end{array}$ & 19 & 2.5 \\
\hline & & Dernek/vakıf & 28 & 3.7 \\
\hline & & Üniversite & 6 & 0.8 \\
\hline & & Kendim çalışıyorum & 50 & 6.7 \\
\hline & & Diğer & 6 & 0.8 \\
\hline & & Toplam & 747 & \\
\hline & \multirow{5}{*}{$\begin{array}{l}26-30 \\
\text { Yaş }\end{array}$} & Aile (Anne, baba, kardeş, amca vb.) & 14 & 28.6 \\
\hline & & KYK burs veya kredi & 11 & 22.4 \\
\hline & & $\begin{array}{c}\text { Aile dışındaki kişiler (İş adamları, } \\
\text { arkadaş vb.) }\end{array}$ & 2 & 4.1 \\
\hline & & Kendim çalışıyorum & 22 & 44.9 \\
\hline & & Toplam & 49 & \\
\hline & \multirow{5}{*}{$31+$ Yaş } & Aile (Anne, baba, kardeş, amca vb.) & 3 & 21.4 \\
\hline & & KYK burs veya kredi & 3 & 21.4 \\
\hline & & Kendim çalışıorum & 7 & 50 \\
\hline & & Diğer & 1 & 7.1 \\
\hline & & Toplam & 14 & \\
\hline
\end{tabular}

* Birden fazla seçenek işaretlenmişstir.

Tablo 9'de araştırmaya katılan üniversite öğrencilerinin mali gelir kaynaklarının yaş gruplarına göre dağılımına yer verilmiştir. Çalışmaya katılan 17-20 yaş grubundaki öğrencilerin, \%59.4'ünün (f=768) mali gelir kaynaklarının aileleri olduğu, 21-25 yaş grubundaki öğrencilerin \%54.1'inin ( $\mathrm{f}=404$ ) mali gelir kaynaklarının ailelerinin olduğu, 26-30 yaş grubundaki öğrencilerin \%28.6'sının (f=14) mali gelir kaynaklarının ailelerinin olduğu görülmektedir. Ayrıca 31+ yaş grubundaki öğrencilerin de \%21.4'ünün (f=3) mali gelir kaynaklarının ailelerinin olduğu, \%21.4'ünün de (f=3) KYK burs veya kredi olduğu elde edilen bulgulardan tespit edilmiştir.

Tablo 10'da araştırmaya katılan üniversite öğrencilerinin sosyal yardımlara erişmede tercih ettikleri yol/yöntem cinsiyet grubu açısından karşılaştırılmıştır. Elde edilen bulgulara göre çalışmaya katılan kadın öğrencilerin \%84.2'si (f=829) sosyal yardımlara erişmede sosyal medya/interneti kullanmakta, erkek öğrencilerin ise \%86.3'ü $(\mathrm{f}=295)$ bu yolu tercih etmektedir. Ayrıca gruplar arasın- da yapılan analize göre herhangi anlamlı bir ilişkiye rastlanmamıștır ( $\mathrm{p}>0.05)$.

Tablo 10. Öğrencilerin cinsiyetinin sosyal yardımlara erişmede tercih edilen yol/yönteme göre dağılımı

\begin{tabular}{|c|c|c|c|c|}
\hline \multirow{2}{*}{\multicolumn{2}{|c|}{ Sosyal medya/Internet }} & \multicolumn{2}{|c|}{ Müracaat şekli } & \\
\hline & & Doğrudan müracaat & Toplam & \\
\hline \multirow{4}{*}{ Cinsiyet } & \multirow{2}{*}{ Kadın } & 829 & 155 & 984 \\
\hline & & 84.2 & 15.8 & 100 \\
\hline & \multirow{2}{*}{ Erkek } & 295 & 47 & 342 \\
\hline & & 86.3 & 13.7 & 100 \\
\hline & \multirow[t]{2}{*}{ Toplam } & 1124 & 202 & 1326 \\
\hline & & 84.8 & 15.2 & 100 \\
\hline
\end{tabular}

Tablo.11 Öğrencilerin yaşlarının sosyal yardımlara erişmede tercih edilen yol/yönteme göre dağılımı

\begin{tabular}{|c|c|c|c|c|}
\hline Müracaat şekli & Yaş & SS & $t$ & $p$ \\
\hline Sosyal medya/internet & 20.24 & 2.499 & & \multirow{2}{*}{-1.724} \\
\cline { 1 - 3 } Doğrudan müracaat & 20.57 & 2.708 & & \\
\hline
\end{tabular}

Tablo 11'de araştırmaya katılan öğrencilerin sosyal yardımlara erişmede tercih ettikleri yol/yöntemleri ile öğrencilerin yaşları karşılaştırılmıştır. Buna göre, sosyal yardımlara erişmede sosyal medya/internet kullananların yaş ortalaması 20.24, doğrudan müracaat edenlerin ise yaş ortalaması 20.57 olarak tespit edilmiştir. Analiz sonucuna göre gruplar arasında anlamlı bir farklılığa rastlanmamıştır( $\mathrm{p}>0.05)$.

Tablo.12 Öğrencilerin okuduğu sınıfların sosyal yardımlara erişmede tercih edilen yol/yönteme göre dağılımı

\begin{tabular}{|c|c|c|c|c|}
\hline \multirow{2}{*}{\multicolumn{2}{|c|}{ Sosyal medya/Internet }} & \multicolumn{2}{|c|}{ Müracaat şekli } & \\
\hline & & Doğrudan müracaat & Toplam & \\
\hline \multirow[t]{12}{*}{ Sinif } & \multirow[t]{2}{*}{ 1. sınıf } & 456 & 70 & 526 \\
\hline & & 86.7 & 13.3 & 100 \\
\hline & \multirow[t]{2}{*}{ 2. sinıf } & 365 & 60 & 425 \\
\hline & & 85.9 & 14.1 & 100 \\
\hline & \multirow[t]{2}{*}{ 3. sinıf } & 155 & 39 & 194 \\
\hline & & 79.9 & 20.1 & 100 \\
\hline & \multirow[t]{2}{*}{ 4. sinif } & 108 & 18 & 126 \\
\hline & & 85.7 & 14.3 & 100 \\
\hline & \multirow{2}{*}{$\begin{array}{c}\text { Ders Dö- } \\
\text { nemi* }^{*}\end{array}$} & 22 & 11 & 33 \\
\hline & & 66.7 & 33.3 & 100 \\
\hline & \multirow{2}{*}{$\begin{array}{c}\text { Tez Dö- } \\
\text { nemi* }\end{array}$} & 18 & 4 & 22 \\
\hline & & 81.8 & 18.2 & 100 \\
\hline & \multirow[t]{2}{*}{ Toplam } & 1124 & 202 & 1326 \\
\hline & & 84.8 & 15.2 & 100 \\
\hline
\end{tabular}

* Yüksek lisans/doktora öğrencilerini belirtmektedir.

Tablo 12'de araştırmaya katılan üniversite öğrencilerinin sosyal yardımlara erişmede tercih ettikleri yol/yöntem okudukları sınıf açısından karşılaştırılmıştır. Elde edilen bulgulara göre çalışmaya katılan lisans ve ön lisans öğrencilerinden 1. sınıf öğrencilerinin \%86.7'si (f=456), 2. sınıf öğrencilerin \%85.9’u ( $\mathrm{f}=365)$, 3. sınıf öğrencilerinin $\% 79.9$ 'u ( $\mathrm{f}=155)$ ve 4 . sinıf öğrencilerinin ise \%85.7'si $(\mathrm{f}=108)$ sosyal yardımlara erişmede sosyal medya/interneti kullanmaktadır. Lisansüstü öğrencilerine bakıl- 
dığında ise ders dönemindeki öğrencilerinin \%66.7'si $(\mathrm{f}=22)$, tez dönemindeki öğrencilerin de \%81.8'inin ( $\mathrm{f}=18)$ sosyal yardımlara erişmede sosyal medya/interneti kullandıkları elde edilen bulgulardan tespit edilmiştir.

Tablo.13 Öğrencilerin medeni durumlarının sosyal yardımlara erişmede tercih edilen yol/yönteme göre dağılımı

\begin{tabular}{|l|c|c|c|c|}
\hline \multirow{2}{*}{ Sosyal medya/Internet } & \multicolumn{3}{|c|}{ Müracaat şekli } & \\
\cline { 3 - 5 } & \multirow{3}{*}{ Medeni durum } & Doğrudan müracaat & Toplam & \\
\hline \multirow{3}{*}{ Bekâr } & & 1085 & 190 & 1275 \\
\cline { 3 - 5 } & \multirow{2}{*}{ Evli } & 85.1 & 14.9 & 100 \\
\cline { 3 - 5 } & & 39 & 12 & 51 \\
\cline { 3 - 5 } & \multirow{3}{*}{ Toplam } & 76.5 & 23.5 & 100 \\
\cline { 3 - 5 } & & 1124 & 202 & 1326 \\
\hline & & 84.8 & 15.2 & 100 \\
\hline
\end{tabular}

$p=.074>0.05$

Tablo 13'te araştırmaya katılan üniversite öğrencilerinin sosyal yardımlara erişmede tercih ettikleri yol/yöntem medeni durumları açısından karşılaştırılmıştır. Elde edilen bulgulara göre çalışmaya katılan bekâr öğrencilerin \%85.1'i ( $\mathrm{f}=1085)$ sosyal yardımlara erişmede sosyal medya/interneti kullanmakta, evli öğrencilerin ise \%76.5'i (f=39) bu yolu tercih etmektedir. Ayrica gruplar arasında yapılan analize göre herhangi anlamlı bir ilişkiye rastlanmamıştır ( $\mathrm{p}>0.05)$.

\section{TARTIŞMA, SONUÇ VE ÖNERILER}

Üniversite öğrencilerinin yaşadıkları ekonomik sorunların boyutunun tespit edilmesi amacıyla yapılan bu çalışmada; maddi açıdan zorlanma düzeyi/maddi ihtiyaçların karşılanma düzeyi ile öğrencilerin aktif çalışma durumları arasındaki ilişki incelendiğinde, öğrencilerin büyük çoğunluğunun çalışmadığı; ancak ihtiyaçlarını karşılayanların da çalışma eğiliminde oldukları görülmüştür. Öğrencilerin çalışma eğilimi göstermelerinde sosyo-ekonomik destek kaynaklarından uzak olmaları, yeterli burs imkânlarının olmaması gibi nedenlerden ötürü bu alternatifleri tercih ettikleri düşünülmektedir. Okul dönemlerinde sosyo-ekonomik sebeplerden ötürü çalışmak zorunda kalan öğrenciler okuldaki aktif faaliyetlere katılmaktan mahrum kalabilmekte bu da okuldaki başarı seviyelerini doğrudan etkileyebilmektedir. Oral ve McGivney (2014), ülkemizdeki sosyo-ekonomik şartlar, öğrencilerin akademik başarısını etkilediğini vurgulamakta; ayrıca sosyo-ekonomik imkanları düşük olan öğrencilerin akademik başarılarının düşük olduğunu ifade etmektedir. Bunun yanında Kurnaz (2007), maddi güçlük çeken ailelerde yetişen kişiler için eğitim en son düşünülen olgudur. Her ne kadar ailesinden uzak olmuş olsa da Albrecht ve Ziderman (1992)'a göre Türkiye' de öğrencilerin mali gelir kaynaklarını başında aile gelmektedir. Dolayısıyla ailenin yükseköğrenim gören çocuklarına parasal katkısı geliri ile orantılı olmaktadır. Bunlardan yola çıkarak ekonomik anlamda güçlük çeken ve bu sebepten ötürü çalışmak durumunda kalan öğrenci ve ailelerinin tespit edilmesi ve kredi ya da burs gibi birtakım imkân- larla desteklenmesinin öğrenci başarısını etkileyeceği ve okuldaki faaliyetlerde daha aktif yer almalarına olanak sağlayacağı düşünülmektedir.

Üniversite öğrencilerinin maddi açıdan zorlanma düzeyleri farklı değişkenler açısından incelendiğinde, kadın öğrencilerin maddi konularda erkek öğrencilere k1yasla daha fazla zorlandıkları görülmüştür. Sınıf değişkeni açısından maddi zorlanma düzeylerine bakıldığında, üniversiteye yeni gelen öğrencilerin üst sınıftaki öğrencilere göre daha fazla zorlandıkları tespit edilmiştir. Medeni durum değişkeni açısından maddi olarak zorlanma düzeyleri incelendiğinde ise bekâr öğrencilerin evli öğrencilere nazaran daha çok zorlandıkları gözlemlenmiştir. Üniversite öğrencileri gerek ailelerinden uzaklaşmaları gerek kendi benliklerinin farkına varmaları gerekse de fizyolojik ya da çevresel faktörlere bağlı olarak hayata karşı bakış açısının değişmesi sonucu dış etkilere karşı açık olma ve üniversite hayatının onlara sunmuş olduğu olanakları belirgin şekilde yaşama eğilimindedir. Yaşın bireye verdiği olgunlukla -bireyin yaşı ilerledikçe- kişi daha sağlıklı kararlar verebilmekte ve ekonomik olarak hayatını daha sağlıklı sürdürebilmektedir. Bu anlamda üniversiteye yeni adım atmış bireylere yönelik okul sosyal hizmeti çatısı altında verilecek destek hizmetleriyle daha da güçlendirilmelerinin sağlanabileceği düşünülmektedir. Toplumun inşasında etkin bir rol alan bu grubun üniversite döneminde ailesinden uzaklaşmasına bağlı olarak yaşadıkları ekonomik sorunlara yönelik oluşturulacak politikalar sağlıklı bir toplumun oluşmasına zemin da hazırlayacaktır.

Üniversite öğrencilerinin mali gelir kaynakları farklı değişkenler açısından incelendiğinde, bütün gruplarda ilk sırada aile (anne, baba, kardeş, amca vb.) ikinci sırada ise KYK burs ve kredileri yer aldığg görülmüştür. Aile dışındaki bireyler (iş adamları, arkadaş vb.), dernek/vakıf, üniversite gibi yerlerden de öğrenciler ihtiyaç duydukları ekonomik kaynaklarını karşılayabilmektedir. Şahin ve diğ. (2009)' a göre, öğrencilerin üniversite okurken en temel sorunu ekonomik zorluklar ve temel gereksinimlerini karşılayamamadır. Öğrenciler eğitimini sürdürmek için ihtiyaç duyduğu paraya yeterli oranda sahip olamama, burs miktarının azlığı ve burs alma olanaklarının yetersizliği, barınma, ulaşım, beslenme konusunda yaşanan güçlükler gibi sorunlarla sık sık karşılaşmaktadır. Öğrenciler ihtiyaçlarını karşılamak için öncelikle ailelerine başvurma eğilimindedir. Fakat ekonomik anlamda zorluk çeken aileler yükseköğrenimde okuyan aile fertlerine sınırlı şekilde destek çıkabilmektedir. Hemen hemen her öğrenciye Kredi Yurtlar Kurumu tarafından ödenen burs veya krediler ise bir noktaya kadar öğrencilerin ihtiyaçlarını karşılayabildiği saptanmıştır. Yavuzer ve diğ. (2005)'e göre, üniversite öğrencilerinin en yaygın beş sorunu arasında; aileye yük olunması, ulaşım sıkıntısı, burs imkânlarının yetersizliği, gelirin giderleri karşılayamaması ve derslerle ilgilenmekten diğer faaliyetler için yeterince zaman kalmaması yer almaktadır. Özkan ve Yılmaz 
(2010)'a göre ise üniversite öğrencilerinin en fazla ekonomik nedenlere bağlı olarak barınma ücretlerini karşılayamaması, sosyal ve kültürel etkinliklere katılamama, okul arkadaşları ve karşı cinsle olan arkadaşlıklarında sorunlar yaşadıkları saptanmıştır. Bu noktada öğrencilerin ekonomik anlamda yükünü azaltacak destek hizmetlerine ihtiyaç duyulduğu görülmektedir. Öğrenciler için ek bir gelir kaynağı oluşturabilecek faaliyet alanlarının varlığı toplumun inşasında etkin rol alan bu grubun ihtiyaçlarına çözüm olacağı d düşünülmektedir.

Üniversite öğrencileri sosyal yardımlara erişmede tercih ettiği yol/yöntemler sosyo-demografik bilgiler ışığında incelendiğinde, cinsiyet, sınıf ve medeni durum ile sosyal yardımlara erişmede kullanılan yol/yöntem arasında bir ilişkiye rastlanmazken öğrencilerin okudukları sınıf düzeyleri ile sosyal yardımlara erişmede kullanılan yol/ yöntem arasında anlamlı bir ilişki gözlemlenmiștir. $\mathrm{Bu}$ durum özellikle 1. ve 2. Sınıf öğrencilerinde göze çarpmaktadır. Çalışma kapsamında elde edilen bu sonuçların yanı sıra gelecekte yapılacak çalışmalarda üniversite öğrencilerinin yaşadıkları maddi sorunlara yönelik derinlikli çalışmaların yapılmasının öğrencilerin karşılaşabilecekleri sorunların tespitine yönelik katkı sağlayacağı düşünülmektedir.

\section{KAYNAKÇA}

Adem, M. (1993). Ulusal Eğitim Politikamız ve Finansmanı. A.Ü. Eğitim Bilimleri Fakültesi Yayınları No: 172, Ankara.

Ağır, M. (2007) Üniversite Öğrencilerinin Bilişsel Çarpıtma Düzeyleri Ille Problem Çözme Becerileri Ve Umutsuzluk Düzeyleri Arasındaki İlişki. Doktora Tezi. İstanbul: İstanbul Üniversitesi.

Albrecht D. ve Ziderman, A. (1992). Financing Üniversities in Developig Countries. The World Bank, PHREE Background Paper Series, Document No: PHREE 92/61.

Avcı, M. (2010). Ergenlikte Toplumsal Uyum Sorunları. Atatürk Üniversitesi Sosyal Bilimler Enstitüsü Dergisi, 7 (1), 39-63.

Deveci, S.H., Çalmaz, A. ve Açık, Y. (2012). Doğu Anadolu'da Yeni Açılan Bir Üniversitenin Öğrencilerinde Kaygı Düzeylerinin Sağlık, Sosyal Ve Demografik Faktörler İle İlişkisi. Dicle Tıp Dergisi, 39 (2), 189-196.

Gizir, C.A. (2005). Orta Doğu Teknik Üniversitesi Son Sınıf Öğrencilerinin Problemleri Üzerine Bir Çalışma. Mersin Üniversitesi Eğitim Fakültesi Dergisi, 1(2), 196-213.

Gülerman, A. (1989). Akademik Danışmanlara Rehberlik Ve Psikolojik Danışman Niteliğinin Kazandırılması, Ankara Üniversitesi Eğitim Bilimleri Fakültesi Yayınları, Yükseköğretimde Rehberlik ve Psikolojik Danışma Toplantısı, Ankara.

Kacur, M. ve Atak, M. (2011). Üniversite Öğrencilerinin Sorun Alanları Ve Sorunlarla Baş Etme Yolları: Erciyes Üniversitesi Örneği. Erciyes Üniversitesi Sosyal Bilimler Enstitüsü Dergisi, 31(2), 273-297.

Karasar, N. (2013). Bilimsel Araştırma Yöntemi. 26. Basım. Ankara: Nobel Yayıncilık.

Kurnaz, Ş. (2007). Çocuk Yoksulluğu. Aile ve Toplum Dergisi, $3(12), 47-55$
Kurul Tural, N.(1996). Türkiye'de Kamu Öğrenim Kredileri Ve Bursları. Ankara University Journal of Faculty of Educational Sciences (JFES) , 29 (1), 49-61.

Oral, I. ve McGivney, E. J. (2014). Türkiye eğitim sisteminde eşitlik ve akademik başarı. Eğitim reformu girişimi raporu.

Özgüven, İ. E. (1992). Üniversite öğrencilerinin sorunları ve baş etme yolları. Hacettepe Üniversitesi Eğitim Fakültesi Dergisi, 7(7), 5-13.

Özkan, S. ve Yılmaz, E. (2010). Üniversite Öğrencilerinin Üniversite Yaşamına Uyum Durumları: Bandırma Örneği. Fırat Sağlık Hizmetleri Dergisi, 5(13), 153-171.

Şahin, D. (1999). Sosyal destek ve sağlık, sağlık psikolojisi. (Edt. Ülgen H. Okyavuz). Ankara: Türk Psikologlar Derneği Yayınları, No: 19.

Şahin, I.., Şahin Fırat, N., Zoraloğlu, Y.E., Açıkgöz, K. (2009). Üniversite Öğrencilerinin Sorunları. e-Journal of New World Sciences Academy, 4(4), 1435-1449.

Yamaç, Ö. (2009). Üniversite Öğrencilerinin Algıladıkları Sosyal Destek İle Stresle Başa Çıkma Stilleri Arasındaki İlişki. Yayınlanmamış Yüksek Lisans Tezi. T.C. Selçuk Üniversitesi Sosyal Bilimler Enstitüsü. Konya.

Yavuzer, H., Meşeci, F., Demir, İ. ve Sertelin, Ç. (2005). Günümüz Üniversite Gençliğinin Sorunları. Hasan Ali Yücel Eğitim Fakültesi Dergisi 1, 79-91.

Yaylacı, G.Ö, (2005) Örgütsel Stres Yönetmede Etkili Kişilerarası İletişim Stratejileri. Amme İdaresi Dergisi, 38 (2), 51-59 